\title{
Net Primary Production of Nymphoides peltata (Gmel.) O. Kuntze Growing on Sandy Sediment at Edosaki-iri Bay in Lake Kasumigaura, Japan
}

\author{
Takayoshi Tsuchiya, Seiichi Nohara and Toshio Iwakuma
}

\begin{abstract}
The seasonal maximum biomass of Nymphoides peltata growing on sandy sediment at the littoral zone of Edosaki-iri Bay in Lake Kasumigaura was only $47.6 \mathrm{~g}$ dry weight $\cdot \mathrm{m}^{-2}$ in late September. Leaf life span was 28 days and thus biomass turnover rate was estimated as 3.4 for 200 days, comparable with those reported for floatingleaved plants and much higher than other herbaceous plants. The yearly net production per unit ground area was estimated at $182 \mathrm{~g}$ dry weight $\cdot \mathrm{m}^{-2}$. This value is smaller than that reported for phytoplankton at the same site and for floating-leaved plants growing at other regions of this lake.
\end{abstract}

Key words : biomass, leaf life span, Nymphoides peltata, net production

\section{Introduction}

Lake Kasumigaura, located $60 \mathrm{~km}$ northeast of Tokyo, is a eutrophic lake in Japan. The water area in $168 \mathrm{~km}^{2}$, while average water depth is only $4 \mathrm{~m}$. Environmental conditions and littoral vegetation vary among sites in this lake. Takahama-iri Bay, located northwest in the lake, is the most eutrophicated area of this lake and the sediment consists of mud. In this bay an annual floating-leaved plant, Trapa natans L., showed high productivity in spite of its small biomass (TsuchiYa and IWAKI, 1983, 1984). The $T$. natans stand can support a large amount of fishes by providing shelter, food and breeding sites (SAKAI et al., 1984) and the heavy algal blooms are frequently observed in summer (TAKAMURA et al., 1987).

In contrast in a southern bay of the lake, Edosaki-iri Bay, water is less eutrophicated than at Takahama-iri Bay. Wind and wave exposure are relatively high and the sediment consists of sand or fine sand. A perennial floating-leaved plant, Nymphoides peltata
(Gmel.) O. Kuntze, has dominated the floatingleaved plant zone at Edosaki-iri Bay, where few plants of $T$. natans were found. Because of different environmental conditions and species composition, the relative importance of the macrophyte vegetation for the carbon and nutrient dynamics at Edosaki-iri Bay may be different from those at Takahama-iri Bay.

In the present study we attempted to estimate net production of $N$. peltata growing on sandy sediments at Edosaki-iri Bay. For floatingleaved plants annual net production is not equivalent to seasonal peak biomass because of high rates of biomass turnover (ВROCK et al., 1983 ; Tsuchiya and IWAKI, 1983 ; 1984 ; Tsuchiya, 1989). Therefore, we measured seasonal biomass and longevity of leaves to estimate net production. Furthermore, the productivity of $N$. peltata was compared with that of phytoplankton in this area and that of $T$. natans growing at Takahama-iri Bay.

\section{Study site}

The study site is located at the inlet of Edosa- 
ki-iri Bay in the southern region of Lake Kasumigaura (Fig. 1). The sediment is sand or fine sand. The wind exposure and velocity of coastal water current are relatively high compared with other regions in this lake. The sampling station was established just outside of the mouth of the River Ono-gawa. The yearly fluctuation range of the water level of Lake Kasumigaura was $40 \mathrm{~cm}$ in 1984 (Fig. 2). Water level was highest in July just after the rainy season, and low in spring and fall.

Zonal distribution of macrophytes was observed at the study site (Nohara et al., 1986). The emergent vegetation dominated by Phragmites australis (Cav.) Trin. ex Steud., Zizania

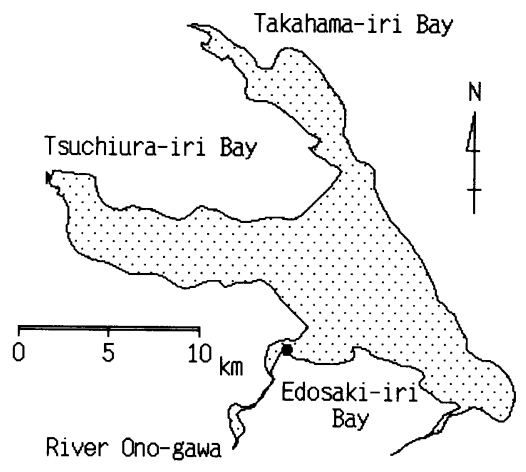

Fig. 1. Study site at Edosaki-iri Bay in Lake Kasumigaura.

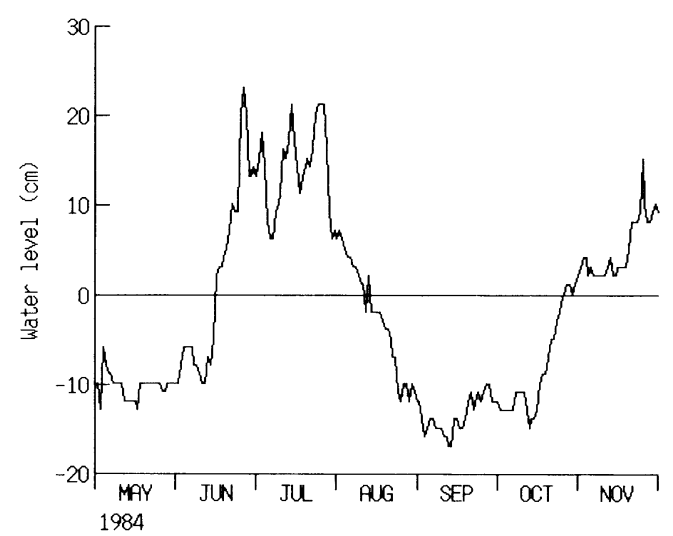

Fig. 2. Seasonal change in deviation from annual mean water level in Lake Kasumigaura in 1984 reported by Erosion and Dam Control Division, Ibaraki Prefecture. latifolia Turcz. and Typha angustifolia L., distributed on the shelf with a gentle slope extending to about $80 \mathrm{~cm}$ of water depth. $N$. peltata occurred almost exclusively the steeper slope, 60-200 cm deep, beyond the shelf. At the $N$. peltata zone, only a little coverage of Trapa natans and several submerged species, Potamogeton malaianus Miq., Potamogeton crispus L., Potamogeton pectinatus L., Potamogeton maackianus A. Benn., and Vallisneria asiatica Miki, were found. Beyond the $N$. peltata zone, i.e., deeper than $200 \mathrm{~cm}$, no submerged vegetation was found.

\section{Materials and methods}

\section{3-1. Determination of biomass}

Once or twice a month from May to November 1984, the aboveground parts of macrophytes were collected from 5-8 quadrats, with an area of $1 \mathrm{~m}^{2}$, at the various water depths.

The plants harvested were brought to laboratory in polyethylene bags and divided into species. $N$. peltata was further divided into its various parts (leaf lamina, petiole and reproductive parts). Biomass of belowground parts (root in the sediment and stem running on the bottom surface) was estimated from the ratio of above- and belowground biomass, which was obtained by harvesting plants in one quadrat, several thousand $\mathrm{cm}^{2}$ in area, at the center of the stand. Epiphytic algae and detritus were cleaned off the samples. After the planimetrical measurement of leaf area using a tablet digitizer (Graphtech Mitablet) and a personal computer (NEC PC9801F2), subsamples of the component parts were dried at $85^{\circ} \mathrm{C}$ for two days to determine dry weight.

\section{3-2. Determination of leaf life span}

$N$. peltata has a roundish floating lamina which is connected with the thin long petiole to the stem at the sediment surface. Leaves of $N$. peltata can be marked easily with colored vinyl tape tied loosely around the petiole. From 20 to 40 leaves of $N$. peltata were marked every two or three weeks from August to November. In this period living leaf number per unit ground area and mean dry weight of a single leaf were approximately constant. Thus, biomass turn- 
over rate of leaf lamina $\left(k\right.$ day $\left.^{-1}\right)$ was estimated using the following equation :

$$
k=\frac{n_{0}-n_{1}}{n_{0}\left(t_{1}-t_{0}\right)},
$$

where $n_{0}$ is the number of leaves marked on a date $t_{0}$ and $n_{1}$ is the number of the leaves remaining on the next census date $t_{1}$. The life span of leaf lamina (day) is defined as the reciprocal of $k$.

Mean life span of petiole was not measured because the leaf marks were easily lost from the laminaless petiole. ВRоск et al. (1983) reported that the life span of the $N$. peltata petiole in the Netherlands is $25 \%$ longer than that of the lamina. We observed that about $15 \%$ of the living petioles were laminaless in October. Therefore, the petiole life span was arbitrarily decided to be $20 \%$ longer than that of leaf lamina.

\section{Results}

Seasonal change in leaf area index of $N$. peltata is shown in Fig. 3. Leaf area index at the sites shallower than $80 \mathrm{~cm}$ was consistently about $0.32 \mathrm{~m}^{2} \cdot \mathrm{m}^{-2}$ from July to November, while that at the sites deeper than $80 \mathrm{~cm}$ decreased in July and increased again to reach the maximum, $0.77 \mathrm{~m}^{2} \cdot \mathrm{m}^{-2}$, in September. This seasonal variation in LAI at the deeper sites was probably caused by seasonal fluctuation in water level (Fig. 2).

Seasonal change in biomass of $N$. peltata averaged for all the depths measured in shown in Fig. 4. Leaf biomass, nearly equivalent to aboveground biomass, was much larger than the other parts throughout the growing period. Few reproductive parts (flower and seed) were produced this year.

$N$. peltata overwinters as a form of tuberous rhizome. In April it began to produce leaves with long petiole and lamina reaching water surface. Stoloniferous rhizome creeping on the sediment was produced during the growing period. Leaves continuously rose from the lateral bud of rhizome. Maximum aboveground biomass was $37.0 \pm 15.6$ (SD, $n=8)$ g dry weight $\cdot \mathrm{m}^{-2}$ in late September. Belowground biomass began to increase after the peak of

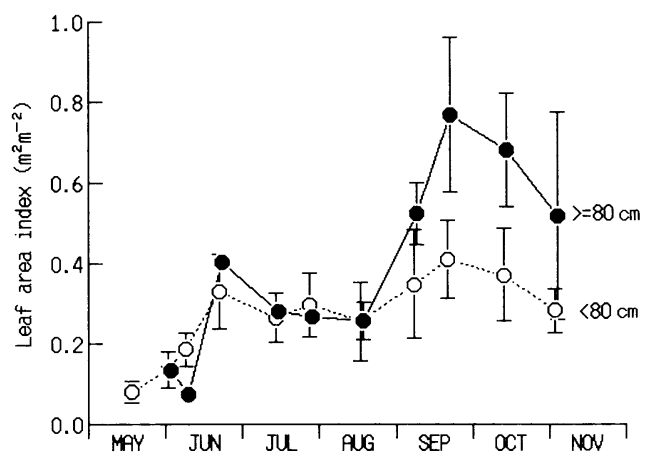

Fig. 3. Seasonal change in leaf area index of Nymphoides peltata at the various water depths in the floating-leaved plant zone ; $\bigcirc$, less than $80 \mathrm{~cm}$; and $\boldsymbol{O}$, over $80 \mathrm{~cm}$ in water depth. Water depth at each site is expressed as the yearly mean value. Vertical bars indicate $95 \%$ LSD.

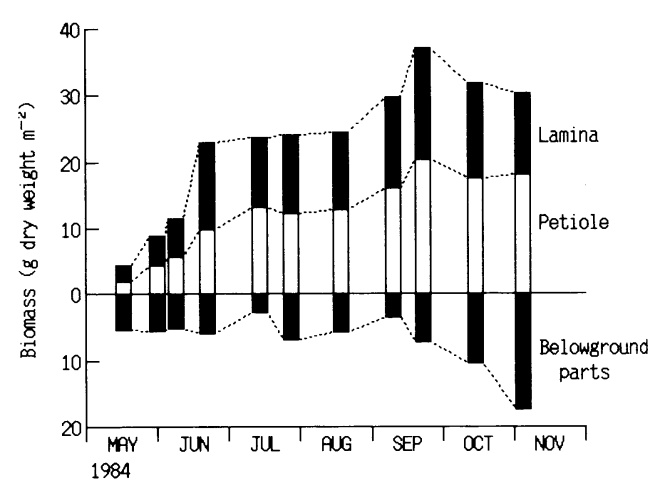

Fig. 4. Seasonal change in above- and belowground biomass of Nymphoides peltata.

aboveground biomass. Consequently, the total biomass of above- and belowground parts reached its maximum, $47.6 \mathrm{~g}$ dry weight $\cdot \mathrm{m}^{-2}$, in November.

Biomass of other floating-leaved and submerged plants under the canopy of $N$. peltata was less than $3 \mathrm{~g}$ dry weight $\cdot \mathrm{m}^{-2}$.

Turnover rate of lamina biomass of $N$. peltata was $0.037 \pm 0.007$ day $^{-1}$ (SD, $\left.n=4\right)$, corresponding to the life span of 28.1 days. Daily net production for lamina and petiole was determined as the biomass multiplied by biomass turnover rate (Table 1 ). Daily aboveground net production was about $1 \mathrm{~g}$ dry weight $\cdot \mathrm{m}^{-2}$. 
Table 1. Daily aboveground (lamina + petiole) net production of Nymphoides peltata determined as the biomass multiplied by the turnover rate.

\begin{tabular}{|c|c|c|c|c|c|}
\hline & \multirow{2}{*}{\multicolumn{2}{|c|}{ Duration }} & \multicolumn{3}{|c|}{$\begin{array}{c}\text { Daily net production } \\
\left(\mathrm{g} \text { dry weight } \cdot \mathrm{m}^{-2} \cdot \text { day }^{-1}\right)\end{array}$} \\
\hline & & & Lamina & Petiole & Aboveground \\
\hline May & 16 - May & 30 & 0.13 & 0.09 & 0.22 \\
\hline May & $30-$ June & 7 & 0.21 & 0.15 & 0.36 \\
\hline June & 7 - June & 20 & 0.37 & 0.22 & 0.59 \\
\hline June & 20 - July & 12 & 0.49 & 0.34 & 0.82 \\
\hline July & 12 - July : & 25 & 0.46 & 0.38 & 0.84 \\
\hline July & 25 - Aug. & 15 & 0.47 & 0.37 & 0.84 \\
\hline Aug. & 15 - Sept. & 6 & 0.52 & 0.43 & 0.94 \\
\hline Sept. & 6 - Sept. & 19 & 0.64 & 0.53 & 1.18 \\
\hline Sept. & 19 - Oct. & 11 & 0.65 & 0.56 & 1.21 \\
\hline Oct. & 11 - Nov. & 1 & 0.51 & 0.53 & 1.04 \\
\hline Nov. & 1 - Dec. & 4 & 0.19 & 0.33 & 0.52 \\
\hline \multicolumn{3}{|c|}{ Total $\left(\mathrm{g} \cdot \mathrm{m}^{-2}\right)$} & 85.45 & 75.80 & 161.25 \\
\hline
\end{tabular}

day $^{-1}$ after July. Thus aboveground net production for 200 days of the growing period amounted to only $161 \mathrm{~g}$ dry weight $\cdot \mathrm{m}^{-2}$, but was 3.4 times as large as maximum biomass. This indicates that a large amount of leaf biomass was continuously lost over the growing periods. In contrast, few belowground parts formed in the current year were lost and they disappeared before the middle of the next growing season. Therefore, yearly belowground net production was approximated to the maximum belowground biomass, $17 \mathrm{~g}$ dry weight $\mathrm{m}^{-2}$. Yearly total net production of $N$. peltata was estimated at $178 \mathrm{~g}$ dry weight $\cdot \mathrm{m}^{-2}$.

\section{Discussion}

$N$. peltata occurs widely in alkaline waters (Smits et al., 1988). Though Lake Kasumigaura is an alkaline eutrophic lake, peak biomass of the $N$. peltata stand at Edosaki-iri Bay was only $47.6 \mathrm{~g}$ dry weight $\cdot \mathrm{m}^{-2}$ with leaf area index of $0.6 \mathrm{~m}^{2} \cdot \mathrm{m}^{-2}$. These values are smaller than those reported for $N$. peltata growing in other regions (IKusima, 1970 ; KvÊT and Husák, 1978 ; VAN der Velde et al., 1979 ; SAKURAI, 1981 ; BRock et al., 1983). The small biomass at Edosaki-iri Bay may be partly because of seasonal fluctuation in water level. Coinciding with a rise in water level, the biomass of $N$. peltata stopped increasing in late June and further decreased at the deep sites (Figs. 2 and 3). Decrease in biomass after a sudden rise in water level causing leaf submergence was also reported for $N$. peltata in the Netherlands (ВRоск et al., 1983) and for Nelumbo nucifera Gaertn. in Lake Kasumigaura (Nohara and Tsuchiya, 1990).

However, one good reason for the small biomass at Edosaki-iri Bay may be the sediment characteristics and exposure to wind and wave action. The highest biomass of $N$. peltata, $425 \mathrm{~g}$ dry weight $\mathrm{m}^{-2}$, was reported for plants growing on the muddy sediment at a sheltered oxbow lake in The Netherlands (BRock et al., 1983). Another floating-leaved plant, Trapa natans L., growing on the muddy sediment at Takahama-iri Bay of Lake Kasumigaura, had a peak biomass over $300 \mathrm{~g}$ dry weight $\cdot \mathrm{m}^{-2}$ (Sakurai, 1981 ; Tsuchiya et al., 1987), while few individuals of $T$. natans were found in the present study site. $T$. natans grows vegetatively by branching in the water column and producing rosette leaves on water surface. Since apical bud is located near the water surface, its damage and loss by heavy wave and wind action seriously affect the following regrowth. In contrast, $N$. peltata has stems usually running on the water bottom. If 
aboveground parts, composed chiefly of leaves, are lost by wave action, the plant can soon recover vegetative growth by producing leaves from the runner. In addition, overwintering shoot bearing roots of $N$. peltata is likely to be less worn down by wave action than seed of $T$. natans. Thus $N$. peltata is supposed to tolerate the high exposure to wave action in spite of small biomass.

Environmental stress may prolong leaf life span (Снавот and Нicкs, 1982) and thus lower the rate of biomass turnover. Leaf life span of $N$. peltata in the present study, 28.1 days, was relatively long compared with those previously reported for the floating-leaved plants (e.g., Euryale ferox Salisb., Hydrocharis dubia Bacher, Nuphar lutea (L.) Sm., Nymphoides peltata, T. natans) ranging from 11 to 35 days (TsuchiYA, 1988). This long life span is possibly related with the sandy sediment because Nymphoides peltata is likely to obtain nutrients primarily from the sediment. The similar value, 27.9 days, was estimated for $N$. peltata grown in an experimental pond with the sandy sediment (Tsuchiya, 1988), while BRock et al. (1983) reported a smaller estimate, 23.1 days, for $N$. peltata attaining large peak biomass supported by the muddy sediment.

The biomass turnover rate of $N$. peltata shown in the present study was similar to or somewhat lower than those reported previously for floating-leaved plants (BRock et al., 1983 ; TSUCHIYA and IWAKI, 1983 ; TwILley et al., 1985 ; Tsuchiya, 1989), but was much higher than those of other macrophytes.

The yearly net production of $N$. peltata at Edosaki-iri Bay was $178 \mathrm{~g}$ dry weight $\cdot \mathrm{m}^{-2}$, corresponding to $82 \mathrm{~g} \mathrm{C} \cdot \mathrm{m}^{-2}$ based on the carbon content of $45 \%$ reported by NoHARA et al. (1988). This value is much smaller than yearly production of the phytoplankton at the $N$. peltata stand $\left(370 \mathrm{~g} \mathrm{C} \cdot \mathrm{m}^{-2}\right.$, TAKAmura et al., 1990). Thus, $N$. peltata is not a predominant primary producer at Edosaki-iri Bay.

\section{Acknowledgements}

We thank Drs. M. Aizaki, T. KawaI, T. Hanazato, N. Takamura and Mr. R. Ueno
(National Institute for Environmental Studies) for their assistance in the field measurements and helpful discussion. Thanks are due to the Erosion and Dam Control Division, Ibaraki Prefecture for providing the data of water level.

\section{摘要 \\ 霞ヶ浦・江戸崎入りの砂質地に生育する 浮葉植物アサザの純生産量}

霞ヶ浦・江戸崎入りの砂質地に生育する浮葉植 物のアサザの成長を調べ, 純生産量を推定した。 葉の寿命が 28 日と比較的短いために, 最大現存量 は $47.6 \mathrm{~g}$ 乾重 $\mathrm{m}^{-2}$ と非常に小さく, 現存量の生育 期間 (200日)の回転率は 3.4 と大きな值であった。 そして,アサザの年間の純生産量は $182 \mathrm{~g}$ 乾重 $\mathrm{m}^{-2}$ と推定された。この純生産量推定值は, 同じ地点 での植物プランクトンや霞ヶ浦の他の地域の浮葉 植物における值よりも小さかった。

\section{References}

Brock, Th. C. M., G. H. P. Arts, I. L. M. Goossen, and A. H. M. Rutenfrans (1983): Structure and annual biomass production of Nymphoides peltata (Gmel.) O. Kuntze (Menyanthaceae). Aquat. Bot. $17: 167-188$.

Снавот, B. F. and D. J. Hicks (1982) : The ecology of leaf life span. Ann. Rev. Ecol. Syst., $13: 229$ 259.

IKUSIMA, I. (1970) : Ecological studies on the productivity of aquatic plant communities. IV. light condition and community photosynthetic production. Bot. Mag. Tokyo $83: 330-341$.

KVÊT, J. and S. HusấK (1978) : Primary data on biomass and production estimates in typical stands of fishpond littoral plant communities. p. 211-216. In D. Dyкyjová and J. KvÊt (ed), Pond littoral ecosystems, Springer-Verlag., New York.

Nohara, S., T. Tsuchiya, T. Iwakuma, N. Takamura, M. Aizaki and A. Otsuki (1988): Nutrient movements in the littoral zone of Edosakiiri Bay in Lake Kasumigaura. Res. Rep. Natl. Inst. Environ. Stud. 117 : 125-139. (In Japanese with English abstract).

Nohara, S. and T. Tsuchiya (1990) : Effect of water level fluctuation on growth of Nelumbo nucifera Gaertn. in Lake Kasumigaura, Japan. Ecol. Res. 5 : 237-252.

Sakai, M., S. Kasuga and M. Takahashi (1984): Biomass and production of fishes at the littoral 
region in Takahama-iri Bay, Lake Kasumigaura. Res. Rep. Natl. Inst. Environ. Stud. 53 : 85-120. (In Japanese with English abstract).

SAKURAI, Y. (1981) : Changes of flora, vegetation area and biomass of aquatic plants in the recent progress of eutrophication in Lake Kasumigaura. Res. Rep. Natl. Inst. Environ. Stud. 22 : 229-279. (In Japanese with English abstract).

Smits, A. J. M., M. J. H. Delyon, G. van der Velde, P. L. M. Steentues, and J. G. M. Roelofs (1988) : Distribution of three nymphaeid macrohytes (Nymphaea alba L., Nuphar lutea (L.) SM. and Nymphoides peltata (Gmel.) O. Kuntze) in relation to alkalinity and uptake of inorganic carbon. Aquat. Bot. 32 : 45-62.

Takamura, N., T. Iwakuma, M. Aizaki, T. Hanazato and A. Otsuki (1986) : Physicochemical features and primary production of epiphytic and planktonic algae in the littoral zone of Edosakiiri Bay in Lake Kasumigaura. Res. Rep. Natl. Inst. Environ. Stud. 96 : 73-100. (In Japanese with English abstract).

Takamura, N., T. Iwakuma, M. Aizaki and M. YASUNO (1990) : Primary production of epiphytic algae and phytoplankton in the littoral zone of Lake Kasumigaura. Mar. Microbial Foodweb (in press).

Tsuchiya, T. (1988) : Comparative studies on the morphology and leaf life span of floating and emerged leaves of Nymphoides peltata (Gmel.) O. Kuntze Aquat. Bot. 29 : 381-386.

Tsuchiya, T. (1989): Growth and biomass turnover of Hydrocharis dubia cultured under different nutrient conditions. Ecol. Res. 4 : 157-183.

Tsuchiya, T. and H. Iwaki (1983) : Biomass and net primary production of a floating-leaved plant, Trapa natans, community in Lake Kasumigaura, Japan. Jpn. J. Ecol. 33 : 47-54.

Tsuchiya, T. and H. IWAKI (1984) : Seasonal changes in photosynthesis and primary production of a floating-leaved plant, Trapa natans L., community in Lake Kasumigaura, Japan. Jpn. J. Ecol. 34 : 367-374.

TsuchiYa, T., S. Nohara and H. IwaKi (1987) : Annual and seasonal variations in biomass of a floating-leaved plant, Trapa natans L. in Takahamairi Bay of Lake Kasumigaura, Japan. Jpn. J. Limnol. 48 : S39-S44.

Twilley, R. R., L. R. Blanton, M. M. Brinson and G. J. DAvis (1985) : Biomass production and nutrient cycling in aquatic macrophyte communities of the Chowan River, North Carolina. Aquat. Bot. 22 : 231-252.

VAN DER Velde, G., T. G. GIESEN and L. A. VAN DER HeIJDEN (1979) : Structure, biomass and seasonal changes in biomass of Nymphoides peltata (Gmel.) O. Kuntze (Menyanthaceae), a preliminary study. Aquat. Bot. $7: 279-300$.

(著者：土谷岳令, 筑波大学生物科学系, 現在：千葉 大学理学部生物学教室, 干 260 千葉市弥生町 1-33; 野 原精一, 岩熊敏夫, 国立公害研究所生物環境部, 現在: 国立環境研究所生物圏環境部, テ 305 茨城県つくば市 小野川 16-2 ; Takayoshi TsuchiYA, Department of Biology, Faculty of Science, Chiba University, 1-33 Yayoi-cho, Chiba 260 ; Seiichi NoHARA and Toshio IwaKuma, Environmental Biology Division, National Institute for Environmental Studies, 16-2 Onogawa, Tsukuba, Ibaraki 305)

Received : 23 March 1990

Accepted : 14 June 1990 